Vol. 16 (2018) pp. 1-14

doi: $10.4467 / 20843925$ SJ.18.001.10815

www.ejournals.eu/Scripta-Judaica-Cracoviensia

\title{
Numismatic Evidence of Jewish Communal Life in Poland ${ }^{1}$
}

\author{
Ira Rezak \\ (M.D. Professor Emeritus \\ Stony Brook University, New York \\ Fellow, American Numismatic Society, New York) \\ e-mail: immobilis@aol.com
}

Key words: tokens, Polish Jewry, material culture, anthropology of Jews, media of exchange, Tsedaka (charity), Shechita (ritual slaughter)

\begin{abstract}
Tokens are nongovernmental circulating media of exchange, as opposed to coins and other official currencies, which are an exclusive prerogative of sovereign authorities. As a commercially active minority community within Poland, Jews of course utilized official nationally issued monies, but they also issued and circulated many forms of tokens to serve varied social, religious, charitable, and commercial purposes. Tokens of non-precious metals and paper were issued by principal Jewish communal authorities; by societies active in maintaining services such as burial, ritual slaughter, education, care of the sick and elderly, and the distribution of alms; and by prominent merchants. The relatively small value and humbleness of such objects, and the fact that their acceptability did not extend beyond the town of their issue, has meant that they were rarely saved and preserved in the course of Jewish migration and during the tumult of wars and pogroms. Therefore, unlike obsolete national coinages, such local tokens have remained virtually unknown and have never previously been collected and studied, either privately or by museums. Recently, metal detectorists at sites of former Jewish habitation have uncovered considerable quantities of metallic Jewish tokens which display a remarkable geographic range and variety of form and function. This paper, based largely on such newly discovered material, presents this rich trove of artifacts for the first time, and attempts to describe and situate their functions within the social and economic context of Jewish communal life in Poland prior to the World War II.
\end{abstract}

Numismatics is the study of currencies, generally accepted means of exchange, typically coins or banknotes, issued by sovereign authorities. Jews played a significant role in the production of coinage in Polish lands during the $12^{\text {th }}$ and $13^{\text {th }}$ centuries, when a series of Piast dynasts, Casimir the Just, Mieszko III, ${ }^{2}$ Przemysław, and others employed

\footnotetext{
${ }^{1}$ This essay is dedicated to the memory of my late father, Nathan W. Rzezak (Ciechanow 1909-New York 1980) and is based on my presentation during the 11th Congress on the European Association for Jewish Studies in Krakow July 2018.

${ }^{2}$ Gumowski 1975.
} 
Jews as mint officials, who produced official thin silver coins with inscriptions in Hebrew letters for more than a century in western Poland. (Fig. 1) Coinage, however, has long been the exclusive prerogative of sovereign rulers so, between the Bar Kochba rebellion in antiquity and the modern State of Israel, no official generally circulating coins could be authorized by Jews. Tokens, on the other hand, which are monetary objects with strictly limited local circulation, were permitted by secular authorities throughout the world. They were consequently also produced by many Polish Jewish communities, organizations, businesses and private individuals in the modern era, principally in the $19^{\text {th }}$ and $20^{\text {th }}$ centuries, and even earlier. It is such specifically Jewish-issued tokens that were used within Poland which are the focus of this essay. Most such tokens were small and poorly made of cheap materials such as lead or brass. (Fig. 2) However, Jewish token currencies made of paper, cardboard and even leather are also known. Representing little monetary value and not legally exchangeable for official coinage, such issues were rarely purposefully preserved by Jews as they migrated from villages to shtetls, and on to cities or to foreign lands; rather they were often lost or perhaps even discarded in their places of original use. Consequently, they have infrequently survived, have only irregularly been noted in literary or secondary sources ${ }^{3}$ and have apparently, with perhaps a single recent exception, ${ }^{4}$ never been systematically collected or considered either by private collectors or museums. In recent years, however, metallic Jewish tokens have increasingly been found in the remains of former Jewish settlements in Poland and other Eastern European countries by archeologists, but more often by amateur metal detectorists who have offered them commercially. ${ }^{5}$ Such metallic tokens, together with Jewish paper currencies and other small artifacts, are material witnesses that were once active agents in Jewish shtetls, and are thus capable of shedding light on selected aspects of communal relationships. This essay, based primarily on materials that have been gathered in private collections, ${ }^{6}$ illustrates and discusses the range of appearances, materials, functions and geographic distribution of this substantially overlooked category of Polish Jewish artifacts.

Why are tokens produced? In general, to facilitate, to monitor, and to control fiscal exchanges within a limited social group. Official money issued by national or regional authorities circulated freely among Jews and non-Jews alike in Poland as elsewhere. However, Jewish concerns about the distribution of charity and food, the organization of ritual slaughter, education, the promotion of local commerce, and the expression of cultural values, could be and were organized and managed more effectively by the employment of token coinages. Token systems offer two advantages to those who control them:

\footnotetext{
${ }^{3}$ Kisch 1953: 167-182, Plates I-IV; Wengeroff 2010.

${ }^{4}$ Paramonov 2018.

${ }^{5}$ It is noteworthy that, along with such tokens, many other artifacts are now also coming to light that are similar in size, style, and technique of manufacture; these include small Jewish medals, amulets, badges, seal impressions and dreidels. While such cultural objects did not repeatedly circulate physically from hand to hand as tokens did, they too may also serve to convey some sense of the material context of Jewish communal life.

${ }^{6}$ The collections of Ira Rezak, Tsadik Kaplan, the late Alex Abezgauz and an anonymous private collector are the sources of the illustrations provided. Unavoidably, some specimens recently unearthed that are depicted in this article will appear quite worn and barely legible.
} 
they facilitate the monitoring of services or products between issuers, intermediates and recipients, but also, perhaps more importantly, such a structure minimizes any temptation agents may have to pilfer monies passing through their hands or, in the case of poor beneficiaries, the possibility of misuse of community charitable funds.

The most common tokens recently uncovered in Poland are small crude objects, made of lead or less commonly of brass, often less than a one centimeter in diameter. A typical specimen reads simply, "prutah from Tiktin", Yiddish for Tykocin in Eastern Poland, and like most such tokens, it is one-side and undated; another is from Kehillah Kedosha (the holy community of) Vishgyor, that is Vishegrad (Wyszogrod) near Warsaw. (Fig. 3) Prutah is the biblical and traditional Hebrew word for any small coin of minimal cash value. How much would that have been worth? Pauline Wengeroff (1833-1916) who grew up in Brisk (Brest-Litovsk), in her famous "Memoirs of a Grandmother" (1908), ${ }^{7}$ recounted that on Rosh Chodesh in the 1840s her mother was accustomed to giving poor children tokens struck in lead inscribed prutah, worth a third of a Polish groshen or one-sixth of a Russian kopeck. (Fig. 4) This use of an unofficial token of negligible value enabled her to make charitable gifts worth less than the smallest official government coin in $19^{\text {th }}$ century Russian Poland, which then would have been a denezhka or half-kopeck. In Poland, as also in contemporary Ottoman Jewish communities, such tokens of minimum value were utilized as modest charitable gifts to the poor by middle-class donors, but they also served the same purpose for indigent religious Jews who also accepted the obligation to give tsedakah but could not afford to donate even the smallest governmental coin. So, by exchanging the smallest official coin for multiple community-issued tokens of lesser value, both Wengeroff's mother and the poorest Jews had the opportunity of fulfilling this mitzvah inexpensively. Pauline Wengeroff explained that such locally authorized prutahs could be spent by their recipients at the stores of Jewish merchants and might also be exchanged for genuine Russian coinage, but only at the offices of the Kehilla (community) from where they had been originally been issued. This use of Jewish tokens to facilitate minimal donations while also restricting their circulation to within the Jewish community was a common practice throughout Eastern Europe as well as the Middle East. In Poland, such tokens bear the names of many specific towns such as Szrensk, Vyshov, Plotzk and Rozenitz. (Fig. 5) Other tokens issued without place names have also been found, some of which may be tentatively associated with particular regions or towns such as Podlasie or Zawiercie, according to the claims of the metal detectorists who have uncovered them. (Fig. 6) Some token types are presently known only from single surviving specimens, while others are known in multiple copies, some of which may display different formats which therefore implies extended usage over a period of years.

Many tokens, though lacking evidence of their particular place of issue, do specify their function as, for example, relating to the poor, thus, prutah le-aniyim (coin for the poor). (Fig. 7) Others display only a few letters as acronyms that indicate or suggest their purpose. The letter peh seemingly often stands for the word prutah in the general sense mentioned above. However, alternatively, peh may signify pas (bread). A widespread customary usage among both Christians and Jews was the issuance of tokens

\footnotetext{
${ }^{7}$ Wengeroff 2018.
} 
distributed to the poor which were specifically to be redeemed either specifically for bread, or for food more generally. ${ }^{8}$ A typical type of Jewish token bearing a severely abbreviated inscription, of which many varieties have been found, is reportedly from Tuchow, near Tarnow. (Fig. 8) The letters are clear enough but, as with all acronyms, interpretation must remain tentative pending confirmation from independent sources. By analogy with other tokens from Poland and from the Ottoman Empire, however, it is quite likely that the upper two letters on another lead token, peh and lamed, signify either prutah le-aniyim or pas le-aniyim. The lower two letters may be read clockwise as a contraction of Kupat Cholim, the Sick Fund, or else counterclockwise, indicating a Chevra Kadisha, an honorific burial society - either type of charitable organization might well have sponsored such a token. Another type of token, which, again, appears in several varieties and is said to be from Podlasie, (Fig. 8) bears the three-letter acronym tsadi, dalet, mem, likely signifying tsedakah dematah (a local charity; matah meaning place in Aramaic). ${ }^{9}$ The imprint Bikur Cholim (visiting the sick) inscribed on yet another token that also carries the term Tsedakah, may indicate either charitable society sponsorship of such an item or else a specific function of this particular token. (Fig. 9) In this latter case the token might have been purchased by householders from the charitable society to give to poor people performing the function of bikur cholim as an ordinary charitable prutah. More likely, however, and there are parallels for such usage elsewhere, such tokens were given directly to poor people by the kehilla as a form of communal compensation for their actual designated service in caring for the homebound sick. ${ }^{10}$ The presumptive issuer of still another typical communal charity token, the Gabbai Tsedakah (the official in charge of charity), is abbreviated on another token which has no place of origin indicated. (Fig. 9) The Yiddish word Bashert (literally, commanded) that also appears on this token may possibly be meant to convey the sense of a biblical mandate for the mitzvah (commandment) of charity. Exceptionally, an actual date, תקפד 5684=1924 CE, appears on the reverse side of the same highly deteriorated token. Taken together with the Wengeroff testimony of the early $19^{\text {th }}$ century, this serves to indicate a general date range of such token usage in Poland as having extended for at least one hundred years, from the early $19^{\text {th }}$ century virtually up to beginning of the World War II.

The tokens illustrated thus far were all cast in lead and have survived in rather poor condition, having almost all been dug up from the soil of former Jewish settlements. However, some tokens were impressed onto other materials and some have even survived in better states of preservation. A one-sided well-struck pewter token of the Chevra Gemillut Chasadim of Matenbuden, a district in Gdansk, is one such example. (Fig. 10) Another, from Porutzk, finely cast in bronze, is well executed, even decorated, and bears the letters peh and lamed, signifying either prutah or pas le-aniyim. A third form of

\footnotetext{
${ }^{8}$ Eklund (1947-1948): vol. LX: 867-875; vol. LXI: 19-28.

${ }_{9}^{9}$ Reiss, Das Blog des Oesterreichschen Juedischen Museums. http://www.ojm.at/blog/2017/07/09/hessdavid-14-maerz-1932 (access: 17.05.2019). "Die Zedaqa demata צדקה דמתא war eine Einrichtung des Wohlfahrtswesens, deren Hauptaufgabe es war, sich um mittellose Kranke, Witwen und Waisen zu kümmern und mittellose Durchreisende, v.a. vor einem Schabbat, zu versorgen".

${ }^{10}$ Kindler 1974: 47-60, Plates, I \& II.
} 
metallic token, pressed onto a thin piece of brass barely six millimeters in height, is explicitly for the poor, le-ani, and clearly states that it is from po (here) in Lida, part of historic Poland although currently in Belarus.

We have noted that the letter peh on charitable Jewish community tokens may signify either prutah, the general term for a charity token, or pas, meaning bread; of course, in almsgiving there may actually be little difference between offering a destitute person an exchangeable token in hand or, more immediately, serving food to the hungry. As previously mentioned, there has long been a widespread tradition in many cultures for food to be dispensed directly to the poor. Various distribution patterns among Jews in Poland are evident in token form; for instance, a poorly preserved brass entry ticket entitled a student to enter the בית התבשיל, bet ha-tavshil (kitchen) of the mesivta (orthodox academy) for a meal. ${ }^{11}$ (Fig. 11) Similar Shpayzeh markn (food checks) entitled the bearer to eat a meal at a particular Folksküche (public soup-kitchen). Some are characteristically anonymous, though having presumably been designed for local usage in small towns their addresses would have been known to their potential users. On the other hand, establishments in larger towns, for example, such as Folksküche and worker's restaurants in Lodz, Lvov and Warsaw, do specify their nature and location. During the German occupation of World War I, when civilian food supplies in Warsaw were particularly limited, advertisements for the distribution of bread to the destitute were distributed, and in the Passover season so were vouchers for the distribution of matzah and sugar. (Fig. 12) Related to the subject of food distribution in Warsaw is a small medal, obviously not of Jewish origin, that comments on the scarcity of food in the city late in 1918. (Fig. 13) "Shoulder to shoulder. A tribute..." sarcastically paraphrases Adam Mickiewicz from a populist, probably socialist point of view. A Polish nobleman and a wealthy farmer are shown as seemingly controlled by a caricatured Jew, and all three are presented as speculators who have cornered the food market to force the unconscionably high prices detailed on the reverse side of the medal.

Tokens for distributing food as well as charity to the poor exist for non-Jewish as well as for Jewish communities, but there are categories of tokens linked to specific traditional Jewish obligations: shechita, (the kosher slaughtering of animals), talmud torah, (education), bikur cholim, (caring for the sick), linas ha-tsedek, (public hospitals and old age homes), and chesed shel emes, (burial of the dead).

Shechita, the ritual slaughter of animals, is a necessity for all Jewish communities, which implies a need for the presence of an approved shochet (ritual slaughterer) in each dorf, shtetl or town. ${ }^{12}$ Even small localities wished to support a shochet and often resorted to guaranteeing his annual income by a fixed retainer. Larger towns, on the other hand, would not wish the local shochet to profit excessively from the execution of this mandatory religious function. Many Jewish communities in Poland, as elsewhere in Europe and the Middle East, sought to control both the fiscal and the ritual aspects of shechita by issuing special tokens. Such tokens were officially sold by the kehilla to owners of animals, to be paid by the customer to the shochet, who in turn

\footnotetext{
${ }^{11}$ The Yeshiva HaMesivta mentioned on this food token was established in Warsaw by the Ger Hassidic sect according to Kedem Auction 62, Jerusalem, August 2018, lot 385.

${ }^{12}$ Berman 1941.
} 
returned them to the kehilla. Thus, the kehilla, rather than market forces or the shochet himself, controlled both the fee structure and the shochet's income independently of volume, by monitoring the exchange of all monies associated with shehita. Such a system also allowed the kehilla to certify the religious reliability of those shochetim who were to be trusted by the community. A coin-like token from the German-speaking community of Posen (Poznan) cites a specific fee. (Fig. 14) Another medallic token from Glogow, dated 1893, indicates that the income from such a fee, here explicitly specified for the slaughter of a fowl, was directly linked to charity for the poor. A paper token from Opole Lubelskie, near Lublin, indicates that the fee was intended for the slaughter of a pigeon. Lead community seals, called plumbas in Yiddish, attached to slaughtered fowl were another way of regulating the kashrut market for the community, shochet, merchant, and consumer alike. While seals obviously did not re-circulate as tokens did, it is worth noting that large numbers of these objects are currently being found in excavations alongside the tokens we have been discussing. Such seals were often dated for evidence of freshness by reference to the weekly Torah portion read in the synagogue; they also often specified that the monies raised by shechita fees had been earmarked for particular communal responsibilities, such as Jewish educational and hospital functions.

Other tokens, conventional chits, seals and medals, issued under the rubric Linas Ha-Tsedek, similarly served to support old age homes and hospitals in Lodz and elsewhere. (Fig. 15) Bikur cholim tokens, as previously noted, were used for general charity and to compensate persons, usually poor, who were delegated to perform sick care on behalf of the community.

Chesed Shel Emes societies, primarily dedicated to the preparation of the dead for proper burial, were ubiquitous and prestigious in Jewish communities worldwide. Such organizations sponsored both charitable tokens for the poor of the type previously discussed but also paper notes for use as temporary emergency local currencies (Fig. 16). They also issued tokens for a variety of more specific purposes, such as a curious voucher used to pay for a droshky to be used in a funeral procession.

All of the tokens considered thus far were intended to circulate exclusively within the Jewish community, having been authorized for specific social or religious purposes. However, especially during times of war and revolution, shortages or insecurity of normal monetary supplies Jews in Poland and elsewhere were involved in the issuance of generally circulating emergency local currencies. In such circumstances, individual Jews, typically well-respected merchants, and trustworthy Jewish communal societies undertook to issue token money, usually in the form of small paper notes or chits that circulated among gentiles and Jews alike. In 1849, Mendel Hauser, a Perpinionspaechter (estate steward) for a Polish nobleman issued a German language note, denominated as Austrian currency and freely convertible into government banknotes, in Rozdol (then part of Austria-Hungary), signing it in both Hebrew and Latin scripts and stamping it in red as well. (Fig. 17) Z. Brahmson, a merchant of Suwalki, issued a small denomination banknote in 1860, as also did J. Palancer, a dealer in tobacco and salt. Both of these notes were denominated in Russian kopeks, Suwalki then being within the Russian Empire, yet no Russian text appears on them. (Fig. 18) Indeed in addition to Yiddish and Polish, the languages of the town's principal inhabitants, explanations in German were included to facilitate significant trade relationships with Germany. Another note, issued 
by a savings and loan association that was guaranteed by a group of Jewish merchants in Zawiercie, a Russian town not yet conquered by the Germans as of Wrzesnia (September) 1914, has an exclusively Polish text. (Fig. 19) Many other Jewish sponsored Jewish paper token currency notes were issued during the tumultuous World War I and Civil War periods in Polish lands. These ranged from a shochet's cooperative in Zvenigorodok, through grocers' associations named Chesed Shel Emes and Linas Ha-Tsedek in anonymous Western Galician towns, and a Talmud Torah society in Limanowa, to an a workers' tea hall in a presently unknown town. (Fig. 20) The point to be noted is that all of the above were denominated variously in kopecks, rubles, marks, fenigs, or kronas, depending upon the date of issue, the specific location, and the fluctuating tides of battle, of populations and of hegemony. A cardboard note originally valued in German pfennigs by a Yiddish-speaking cooperative named "Gegenzeitigeh Hilf" (mutual help) in Lodz in 1917 was later re-purposed in 1920 for a workers cooperative, but by then the text was partially in Polish and the note was now denominated in Polish marks. As far east as Grodno, a Worker's Cooperative chose to explain in the four languages then current there which foodstuffs a one-mark note could buy.

All of the examples presented thus far range in date from 1849 to just before World War II, but there is definite albeit sparse evidence for the even earlier use of Jewish token currency in Poland. Two remarkable earlier Jewish tokens, each apparently a unique survivor but both preceding the $19^{\text {th }}$ century are worthy of note even though their purposes are at present unclear. (Fig. 21) One is formed from a piece of leather that had been stamped twice, undoubtedly with the expectation that it later would be cut into two separate tokens. While barely legible, careful examination shows abbreviations: קיד קטיק and קהילה קדושה אטוואצק פיש (The Holy Community of Otwock), and be-

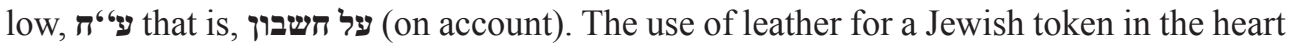
of Poland is otherwise unknown, but the Russian Empire is one of the few places where leather is known to have been used for tokens, from the Middle Ages up to the reign of Peter the Great. In fact, the very word ruble derives from the Russian verb meaning 'to cut', and late medieval small Russian copper coins under Mongolian influence were called puli, a term which seems to have been cognate with leather in their language. What sort of function such Jewish leather tokens were meant to serve in Otwock is uncertain.

Another noteworthy early Jewish survival is a copper token that was produced by stamping a Hebrew text onto a normal $17^{\text {th }}$-century Polish coin of the time of Jan II Casimir. The underlying coin is a so-called boratynka, a type of copper coin that was struck in large numbers in Poland and Lithuania under the aegis of an Italian mintmaster named Tito Livio Burattini between 1659 and 1683 and which continued to circulate there for many decades thereafter. The Jewish token in question is thus a $17^{\text {th }}$-century Polish coin withdrawn from regular circulation that was re-purposed as a token by being struck with a metal die to produce an impression with abbreviations: צבל tsadi lamed presumably stands for צ' בדקה לעני "charity for the poor", an expression documented on many later toשישוה פרוטה שיה (worth a prutah) although it might conceivably indicate שיחיטת פרה, "the slaughter of a cow"... an uncertain but tempting speculation.

To conclude, the examples presented indicate that many Jewish communities in Poland, their social and religious societies, as well as Jewish merchants, regularly issued 
tokens as forms of unofficial currency with limited local circulation for a wide variety of purposes. The presently available evidence strongly supports the idea that such tokens were widely employed in Jewish settlements throughout Poland (as well as elsewhere) during the $19^{\text {th }}$ and early $20^{\text {th }}$ centuries and, almost certainly, played some role earlier as well. Their considerable range of functions, breadth of geographic distribution, and variability of issuing authorities all point to a substantial integration of the use of such tokens within Jewish communal life. It seems reasonable to assume that further research into the scope and usage of this hitherto underutilized source of evidence may further enrich our perception and understanding of Jewish culture in Poland.

\section{BIBLIOGRAPHY}

\section{Primary literature}

Berman, J.J. (1941), Shehitah: A Study in the Cultural and Social Life of the Jewish People, New York. Eklund, O.P. (1947-1948), Charity Tokens of the Netherlands, The Numismatist, vol. LX, December 1947: 867-875; vol. LXI, January 1948: 19-28.

Gumowski, M. (1975), Hebräische Münzen im Mittelalterichen Polen, Gratz.

Kindler, A. (1974), "אסימוני קהילות יהודיות עם כתובות עבריות" (Jewish Communiy Tokens with Hebrew Inscriptions), Alon-Internal Quarterly of the Israel Numismatic Society, vol. V, no. 3 (April): 4760, Plates, I \& II.

Kisch, B. (1953), Jewish Community Tokens, Historia Judaica, vol. XV: 167-182, Plates I-IV.

Paramonov, O.V. (with the active participation of Daniel and Ellen Morozoff-Abezgauz) (2018), Jewish Banknotes, Based on the Collection of A. Abezgauz, Moscow (in Russian and with an English translation by A. Burlyga).

Wengeroff, P. (2010), Memoiren einer Grossmutter: Bilder aus der Kulturgeschichte der Juden Russlands im 19. Jahrhundert Berlin 1908. Retranslated and re-published by Shulamit S. Magnus as Memoirs of a Grandmother Scenes from the Cultural History of the Jews of Russia in the Nineteenth Century, vol. I (Stanford Studies in Jewish History and Culture).

\section{Internet sources}

Reiss J., Das Blog des Oesterreichschen Juedischen Museums, http://www.ojm.at/blog/2017/07/09/ hess-david-14-maerz-1932 (access: 17.05.2019). 


\section{FIGURES}

Where no date is specified the token is undated and presumed to be late $19^{\text {th }}$ to early $20^{\text {th }}$ century.

Illustrations of specimens are courtesy of Tsadik Kaplan [TK], Daniel Morozoff-Abezgauz [DMA], and Ira Rezak [IR].

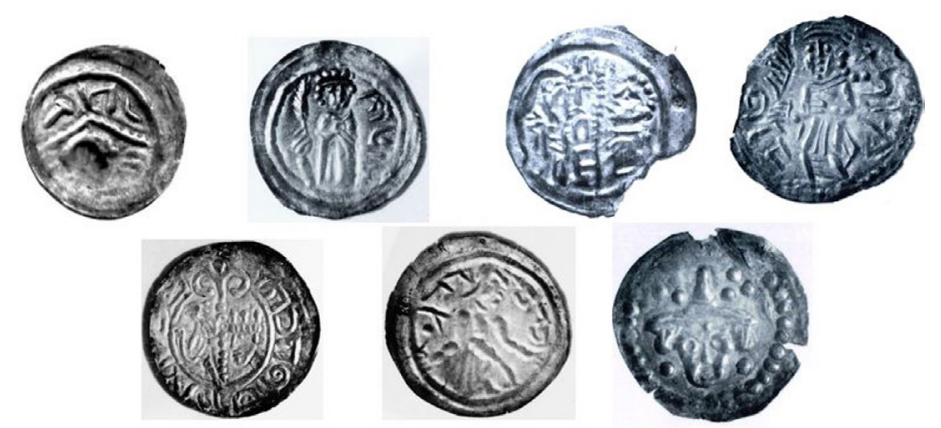

Fig. 1. Medieval Polish coins produced by Jewish mintmasters, $12-13^{\text {th }}$ century. The coin in the upper right is from Wroclaw and represents St. John (יהן) [IR]; The other coins are from the reign of Miesz-

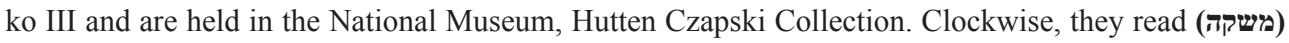

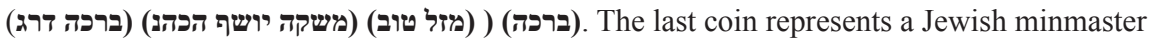

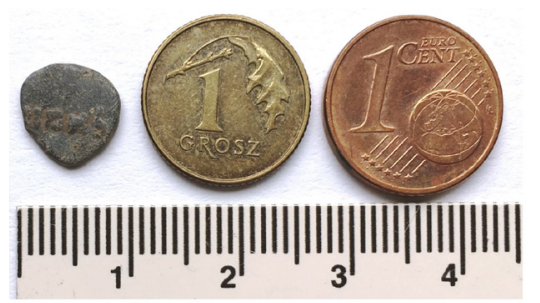

Fig. 2. Lead token: Lomza (לאמזא) [IR]. Modern coins for size comparison
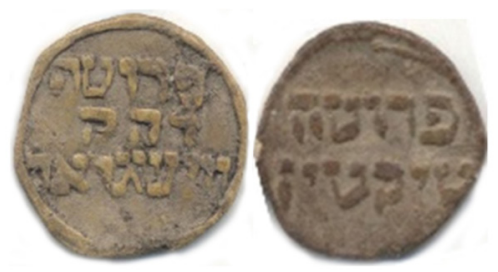

Fig. 3. Lead tokens: Wyszogrod (פרוטה זקק וויששגראד) [TK] and Tykocin (טיקטין) [IR] 


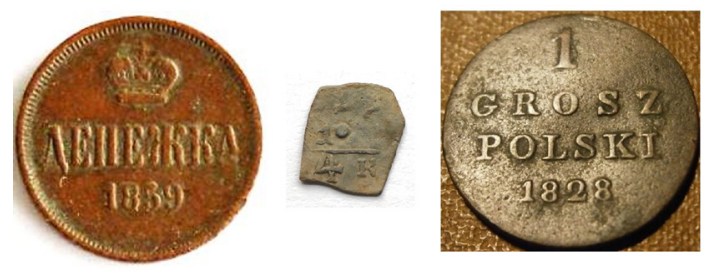

Fig. 4. Lead 1/4 Kopek Poland $19^{\text {th }}$ century [IR], Denezhka (1/2 Kopek) 1859 [IR], Grosz 1828 [IR]

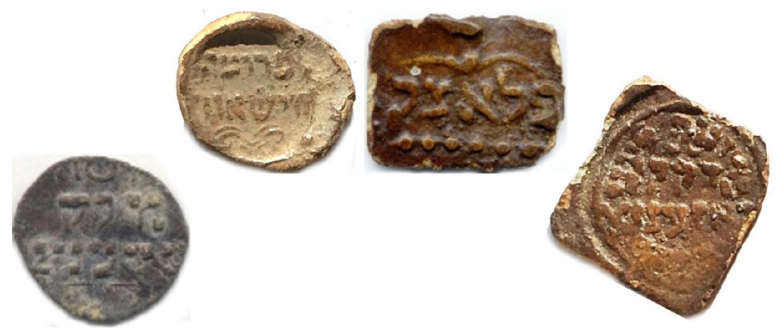

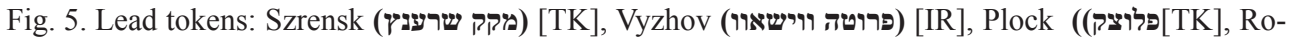
zenitz ( (פרוטה לעני ראזעניץ[IR]
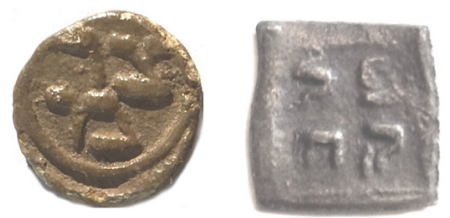

Fig. 6. Anonymous lead tokens: (פצ (פד) (found in Podlasie \& Zaglebie) [IR]
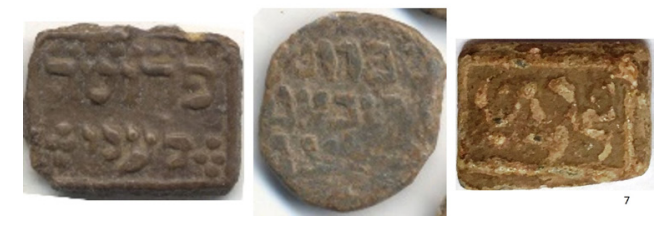

Fig. 7. Anonymous lead tokens: (פרוטה לעני) [TK], [IR]

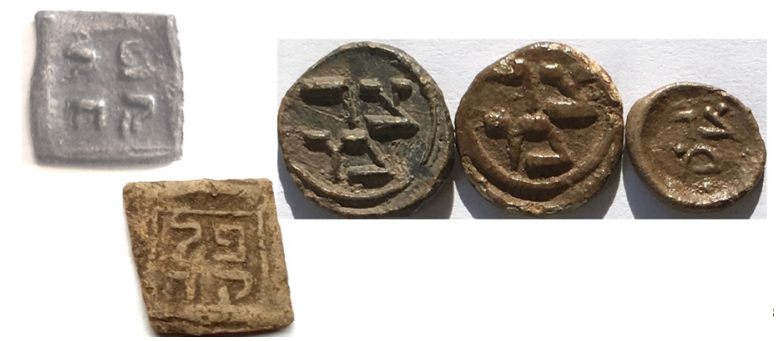

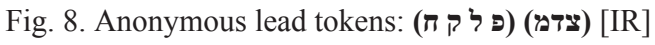



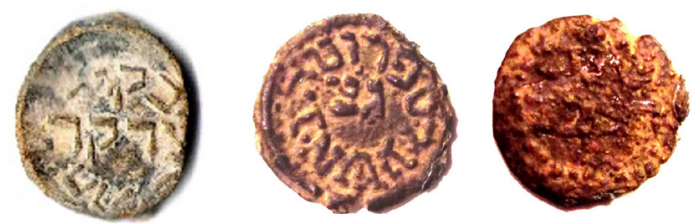

Fig. 9. Lead tokens: Visiting the Sick (בקור חולים צדקה) [IR], Gabbai Tsedaka (ג׳צ פרוטה באשערט) [IR]
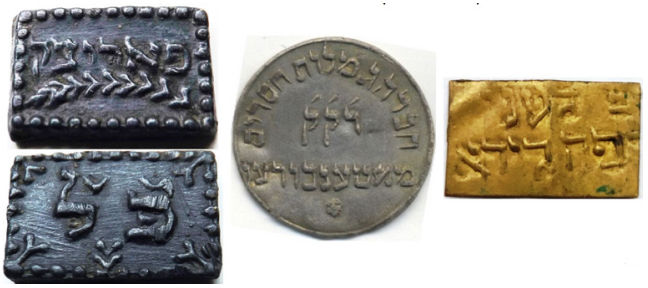

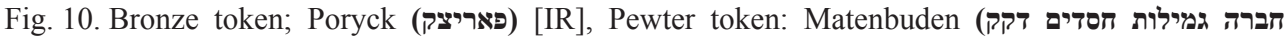
(מאטענבודען) [TK], Brass token: Lida (פ לעני פה לידא) [IR]
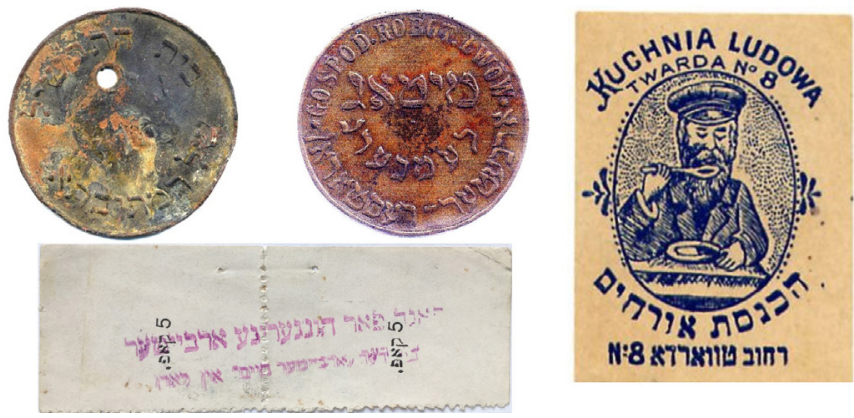

Fig. 11. Food tokens: Kitchen of the Yeshiva, Warsaw (בית התבשיל תל המתיבתא) [TK], Worker's Res-

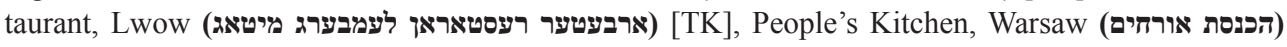

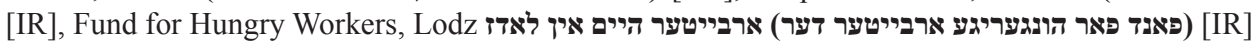
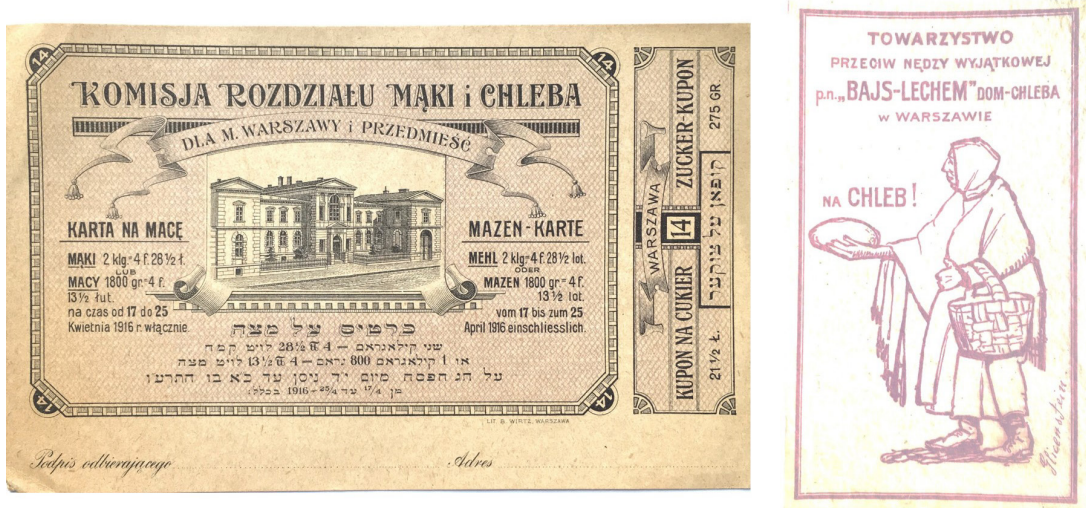

Fig. 12. Matzah Distribution token, Warsaw, Passover, 1916 [IR], House of Bread, Warsaw [IR] 

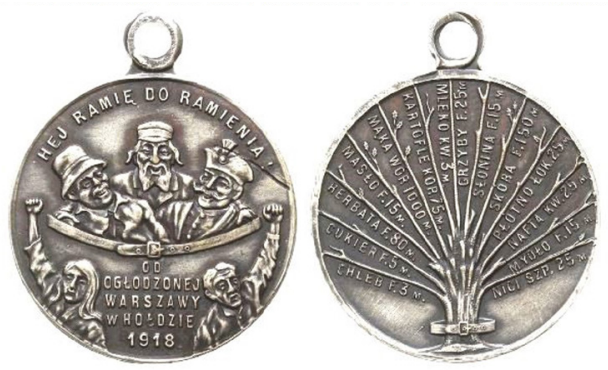

Fig. 13. Copper-Nickel Satirical Medal about high food prices in Warsaw, 1918 [IR]
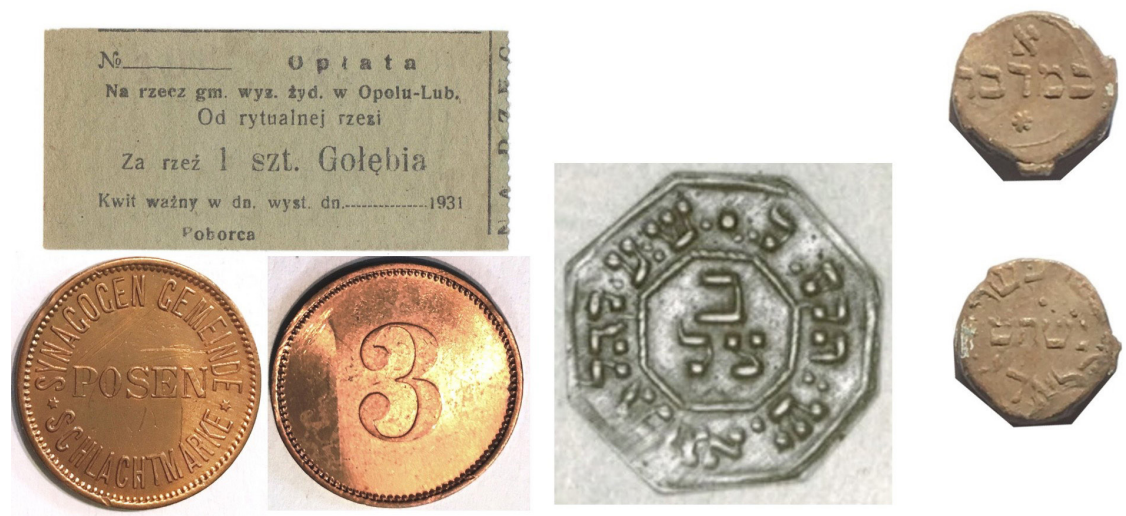

Fig. 14. Ritual Slaughter (Shechita): Token for shechita of a pigeon, Opole, 1931 [IR], Copper token for shechita, Poznan [IR], Copper-Nickel token for shechita of a chicken, Glogow שע קהל גלוגא) תקס ב צ) [IR], Lead Kosher seal for Chicken, slaughtered on Sunday during the week of the Torah reading of Bamidbar (Numbers), Lodz [IR]
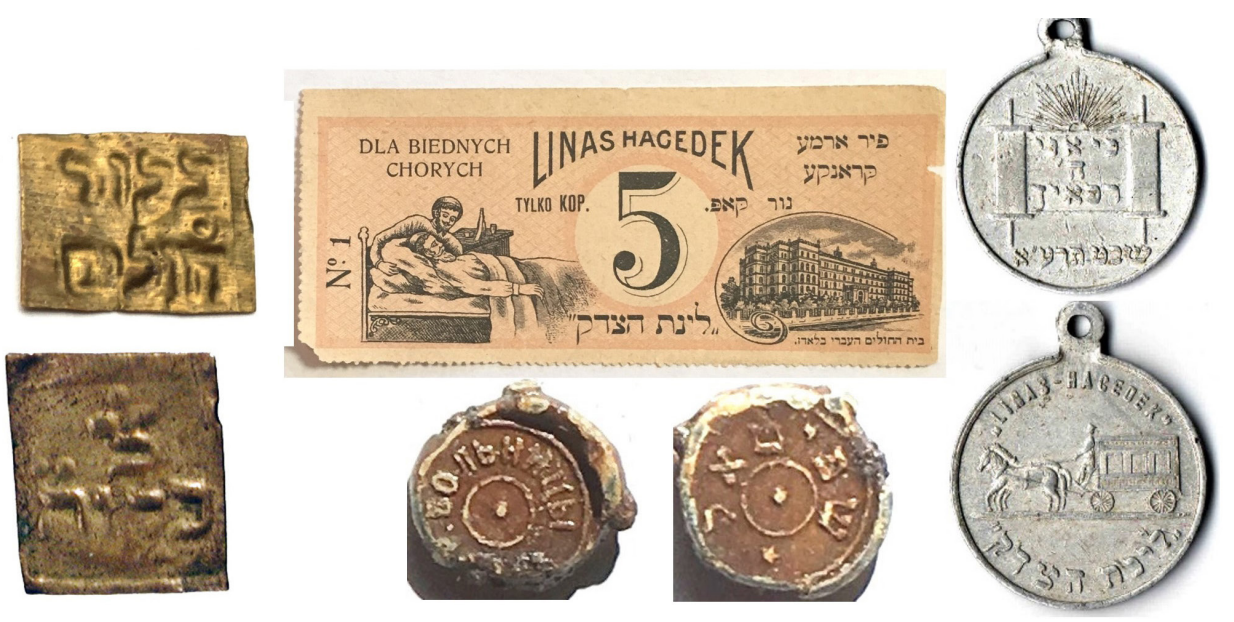

Fig. 15. Sick Care: Two brass tokens for Visiting the Sick (בקור חולים) (לצ בקו הת) [IR], Paper token for the Jewish Hospital in Lodz (לינת הצדק) [IR], Aluminum Medal for the same Hospital, Lodz, 1911 [IR] 

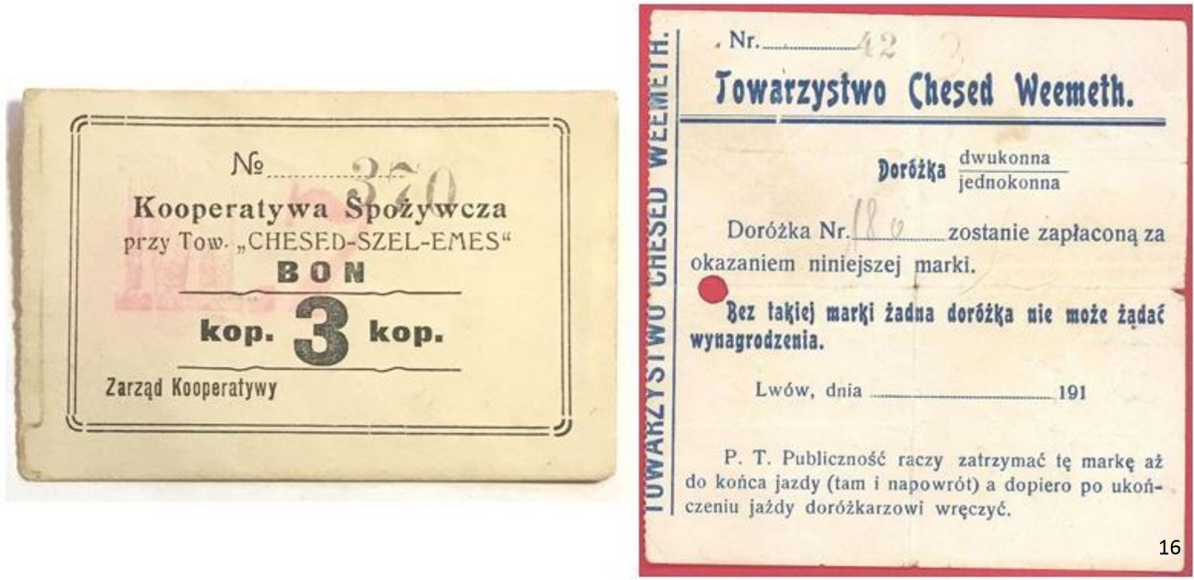

Fig. 16. Burial Societies: Paper currency token, Food Cooperative operated by a Burial Society [IR], Paper token for the rental of a carriage from the Burial Society, Lodz, c. 1910 [IR]

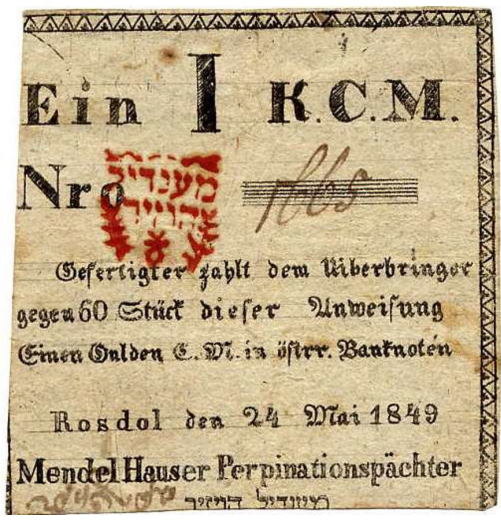

Fig. 17. Personal Voucher of Mendel Hauser, Estate Steward in Rosdol, 1849 [IR]
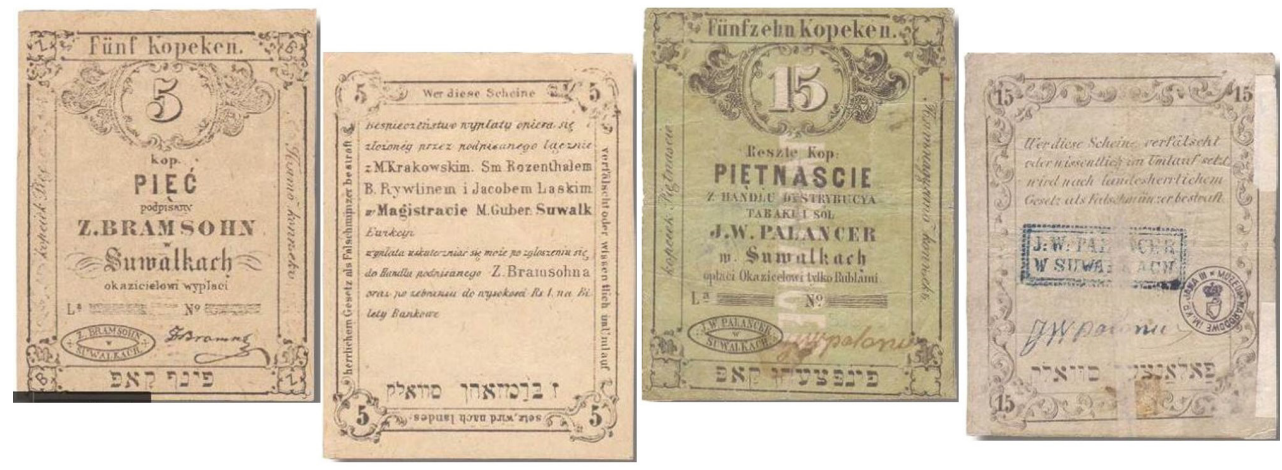

Fig. 18. Paper Circulating Currency notes by Jewish Merchants, Z. Brahmsohn and J.D. Palancer, in Suwalki, c. 1860 [DMA] 


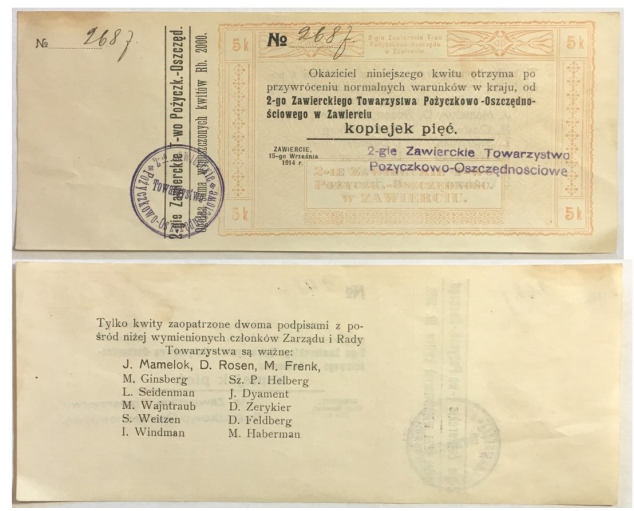

Fig. 19. Emergency Circulating Currency notes by Jewish Merchants in Zawiercie, September 1914 [IR]

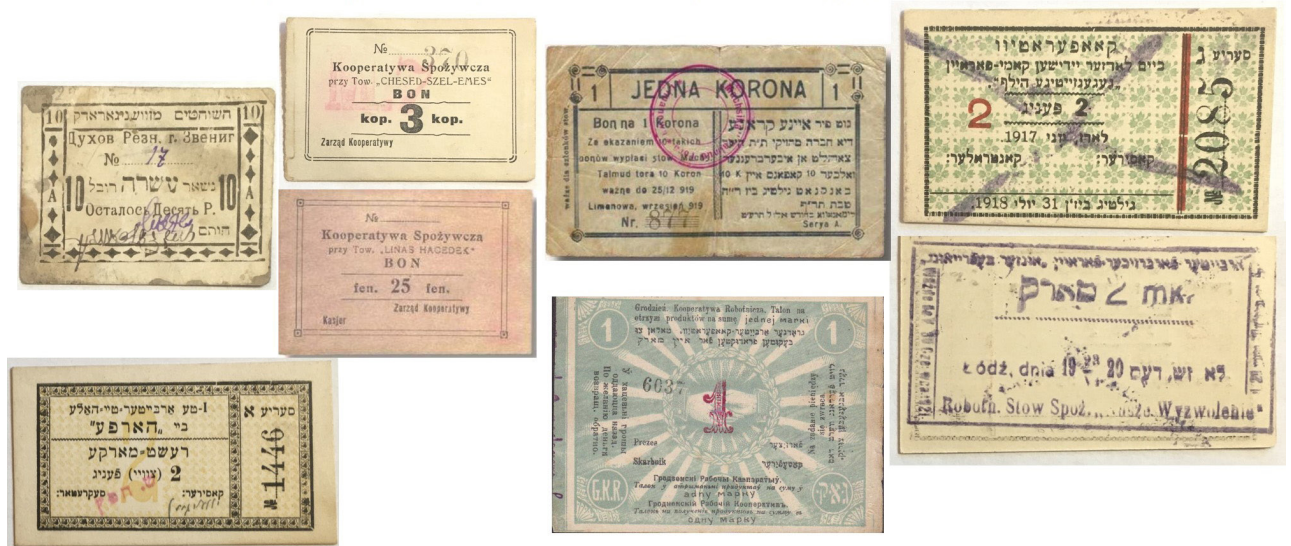

Fig. 20. Locally Circulated notes by Jewish Cooperatives, Societies and Restaurants: The Ritual Slaughterers in Zvenigorodk (השוחטים מזווביגאראדק) [IR], Worker's Tea Hall "Harp" (טיפה (1) ארבייטער :1) טיי האלע ביי 'הארפע' [IR], Food Cooperatives sponsored by Burial and Hospital Societies [DMA], Talmud Torah Society in Limanowa, 1919 [DMA], Workers Cooperative in Grodno [DMA], Self-Help Society in Lodz, 1918 but later reused by a Worker's Society "Our Liberation" in 1920 [IR]

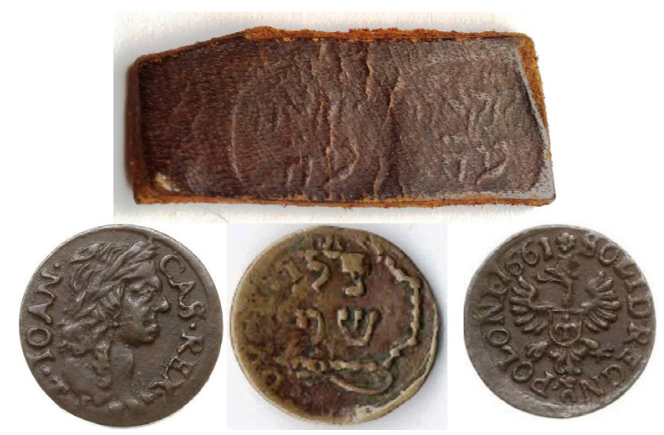

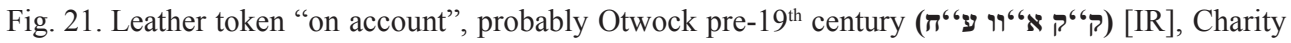

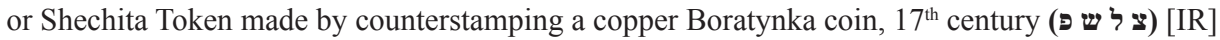

